\title{
GAMBARAN KADAR HEMOGLOBIN(Hb) dan LEUKOSIT PADA PENDERITA TB PARU DENGAN LAMANYA TERAPI OAT (OBAT ANTI TUBERCULOSIS) DI RUMAH SAKIT ISLAM JAKARTA CEMPAKA PUTIH
}

\author{
Atna permana ${ }^{1)}$ \\ ${ }^{1}$ Program Studi Analis Kesehatan, Fakultas Kesehatan, Universitas Mohammad Husni Thamrin \\ Correspondence author: Atna Permana, , atnap@yahoo.com, Jakarta, Indonesia
}

\begin{abstract}
ABSTRAK
Penderita TB Paru masih banyak di Indonesia termasuk di Ibu kota Jakarta. Efek yang timbul baik yang melaksanakan pengobatan maupun yang sementara pengobatan adalah anemia.

Tujuan penelitian memperoleh gambaran kadar hemoglobin dan leukosit pada penderita TB Paru di Rumah Sakit Islam Cempaka Putih. Penelitiang ini menggunakan metode deskriptif populasi dalam penelitian ini adalah penderita TB paru yang masih melakukan pengobatan.

Hasil penelitian menunjukan bahwa kadar hemoglobin penderita TB paru di RSIJ Cempaka Putih sebanyak 34 orang (31\%) memiliki kadar hemoglobin yang normal dan sebanyak 75 orang (69\%) memiliki kadar hemoglobin yang tidak normal, sedangkan nilai rata-rata leukosit sebanyak 70orang (64\%) memiliki nilai leukosit yang normal dan 39 orang (36\%) memiliki nilai leukosit yang tidak normal.

Dari hasil penelitian dapat disimpulkan sebanyak 75 orang $(69 \%)$ memiliki kadar hemoglobin yang tidak normal dan 39 orang (36\%) memiliki nilai leukosit yang tidak normal.
\end{abstract}

Kata kunci : Hemoglobin, Leukosit, Penderita TB, OAT

ABSTRACT

Pulmonary TB sufferers are still many in Indonesia including in the Capital city of Jakarta. The effect that arises both the treatment and the temporary treatment is anemia.

The purpose of the study obtained an overview of hemoglobin and leukocytes levels in people with Pulmonary TB at Cempaka Putih Islamic Hospital. This study uses a descriptive method of population in this study is a lung TB sufferer who is still doing treatment.

The results showed that hemoglobin levels of pulmonary TB patients in RSIJ Cempaka Putih as many as 34 people (31\%) have normal hemoglobin levels and as many as 75 people (69\%) has abnormal levels of hemoglobin, while the average leukocytes are 70people (64\%) have a normal leukocytes value and 39 people (36\%) has abnormal leukocytes.

From the results of the study can be concluded as many as 75 people (69\%) had abnormal levels of hemoglobin and 39 people (36\%) has abnormal leukocytes.

Keywords : Hemoglobin, Leukocytes, TB Sufferers, OAT 


\section{PENDAHULUAN}

Tuberkulosis (TB) sudah menjadi permasalahan kesehatan jutaan orang di dunia. Tuberkulosis menjadi penyebab utama kedua kematian dari penyakit menular di seluruh dunia, setelah Human Imunodeficiency Virus (HIV). Tuberkulosis merupakan penyakit menular yang disebabkan oleh infeksi bakteri Mycobacterium tuberculosis. Penyakit ini menular langsung melalui droplet orang yang telah terinfeksi kuman/basil tuberkulosis (Mycobacterium tuberculosis). Gejala utamanya adalah batuk selama 2 minggu atau lebih, batuk disertai dengan gejala tambahan yaitu dahak, dahak bercampur darah, sesak nafas, badan lemas, nafsu makan menurun, berat badan menurun, malaise, berkeringat malam hari tanpa kegiatan fisik, demam lebih dari 1 bulan. (Najmah, 2016)

Lembaga kesehatan dunia World Health Organization (WHO) pada tahun 2013 mendeklarasikan kedaruratan global tuberkulosis karena sebagian besar Negara-negara di dunia tidak berhasil mengendalikan tuberkulosis sehingga rendahnya angka kesembuhan penderita tuberkulosis yangt berdampak pada tingginya tingkat penularan. Kasus TB di dunia diperkirakan sebanyak 9 juta orang sakit dengan TB dan 1,5 juta meninggal akibat penyakit ini di 22 negara di dunia pada tahun 2013, di perkirakan 37 juta jiwa diselamatkan melalui diagnosis dan pengobatan TB (Najmah, 2016)

Indonesia merupakan negara penyumbang kasus TB paru terbesar kedua di dunia setelah India, yang setiap tahunnya diperkirakan terdapat penderita baru TB paru menular sebanyak 176.677 kasus baru (Kemenkes RI, 2014). Kemudian pada tahun 2015 mengalami peningkatan jumlah kasus baru sebanyak 188.405 kasus baru (Kemenkes RI, 2015). Namun, mengalami penurunan sebanyak 156.723 kasus baru (Kemenkes RI, 2016).

Pengobatan TB tidak terlepas dari adanya efek samping yang ditimbulkan dari OAT. Isoniazid memiliki efek samping hepatitis, neuritis perifer, hipersensitivitas. Rifampisin menimbulkan berbagai efek samping antara lain gastrointestinal, reaksi kulit, hepatitis, trombositopenia, peningkatan enzim hati, cairan tubuh berwarna orange kemerahan. Pirazinamid memiliki efek samping antara lain toksisitas hati, artralgia, gastrointestinal. Etambutol memiliki efek samping neuritis optik, ketajaman mata berkurang, buta warna merah hijau, penyempitan lapang pandang, hipersensitivitas, gastrointestinal, sedangkan obat streptomisin memiliki efek ototoksik, dan nefrotoksik (Bestari dan Adang, 2014).

Hemoglobin $(\mathrm{Hb})$ merupakan zat protein yang ditemukan dalam sel darah merah, yang memberi warna merah pada darah. Hemoglobin terdiri atas zat besi yang merupakan pembawa oksigen. Tujuan pemeriksaan hemoglobin antara lain untuk memantau kadar hemoglobin dalam sel darah merah, untuk membantu mendiagnosis anemia (Kee, 2007).

Sel darah merah berfungsi mengangkut $\mathrm{O} 2$ ke jaringan dan mengembalikan (CO2) dari jaringan ke paru, untuk mencapai hal ini sel darah merah mengandung protein spesial yaitu hemoglobin. Tiap sel darah merah mengandung 640 juta molekul hemoglobin ( $\mathrm{Hb}$ ). Nilai umum kadar $\mathrm{Hb} 4$ adalah kurang 
dari 13,5 g/dL pada pria dewasa dan kurang dari 11,5 g/dL pada wanita dewasa, penurunan kadar $\mathrm{Hb}$ dibawah nilai normal didefinisikan sebagai anemia. Anemia adalah fitur utama pada pasien dengan infeksi bakteri, terutama infeksi yang berlangsung lebih dari satu bulan, termasuk tuberkulosis paru di mana mekanisme yang tepat dari anemia pada TB paru tidak jelas diketahui (Devi dkk dalam Lasut, 2014).

Pengobatan TB dengan OAT dapat menurunkan jumlah leukosit, yang sebelumnya meningkat jumlahnya karena terjadi infeksi, sehingga setelah beberapa bulan pengobatan didapatkan hasil jumlah leukosit dan hitung jenis leukosit dalam jumlah yang normal kembali (Bestari dan Adang, 2014). Menurut penelitian Kassa, dkk (2014) di Ethiopia menyatakan bahwa pada pasien TB menunjukkan hasil yang signifikan dimana terjadinya penurunan kadar nilai Hematokrit $(\mathrm{Ht})$, Hemoglobin $(\mathrm{Hb})$, dan Trombosit setelah mengkonsumsi OAT selama 2 bulan.

Banyaknya jumlah penderita TB paru di RS Islam Jakarta Cempaka Putih sehingga banyak juga permintaan pemeriksaan hemoglobin dan leukosit untuk membantu memantau perjalanan penyakitnya. (RSIJ Cempaka Putih)

Berdasarkan latar belakang di atas, maka peneliti telah melakukan penelitian dengan judul "Gambaran Kadar Hemoglobin dan Leukosit Darah pada Penderita TB Paru dengan lamanya Terapi OAT di Rumah Sakit Islam Jakarta Cempaka Putih Tahun 2019”.

\section{METODE PENELITIAN}

Penelitian di lakukan di Laboratorium RSIJ Cempaka Putih pada tanggal 9 - 27 Juli Tahun 2019. Populasi pada penelitian ini adalah seluruh penderita TBC yang menggunakan Obat Anti Tuberkulosis(OAT) Di Rumah sakit Islam Jakarta Cempaka Putih pada periode Bulan Januari sampai Juli 2019. Sampel penelitian ini adalah data penderita tuberkulosis paru yang melakukan pemeriksaan kadar hemoglobin dan leukosit dengan medical recond pada bulan periode Januari sampai juni 2019. Penelitian menggunakan rumus besar sampel Slovin desain penelitian cross sectional dikarenakan jumlah populasinya sudah diketahui. Populasi penelitian berjumlah 150 orang pasien, peneliti menggunakan tingkat kepercayaan 95\%.

\section{Rumus besar sampel :}

$$
\mathrm{n}=\frac{\mathrm{N}}{1+\left(\mathrm{N} \cdot \mathrm{e}^{2}\right)}=\frac{150}{1+\left(150 \times 0,05^{2}\right)}=109,09=109
$$

Keterangan :

$\mathrm{n}=$ Jumlah sampel minimal

$\mathrm{N}=$ Populasi

$\mathrm{E}=$ Tingkat error/alpha

Jadi jumlah sampel minimal yang diperlukan sebanyak 36 responden. 
Penelitian ini dilakukan dengan cara pengumpulan data sekunder dari instalasi patologi klinik RSIJ Cempaka Putih dengan tahapan : Melakukan observasi dan penyerahan prosedur izin pengambilan data pada bagian dari instansi patologi klinik RSIJ Cempaka putih. Mengajukan izin pengambilan data ke bagian laboratorium dengan membawa surat izin pengambilan data dari pihak akademik. Melakukan pengambilan data di instalasi patologi klinik RSIJ Cempaka Putih. Mencatat hasil pemeriksaan pada komputer dari instalasi patologi klinik RSIJ Cempaka Putih. Mencatat data-data pendukung seperti nama, usia, dan jenis kelamin. Data yang diperoleh dalam penelitian ini adalah secara deskriptif dalam bentuk presentase dan disajikan dalam bentuk tabel disertai dengan narasi.

$$
\frac{A}{B} \times 100 \%=X \%
$$

Keterangan :

$$
\begin{array}{ll}
\mathrm{A} & =\text { Jumlah variable yang akan dihitung } \\
\mathrm{B} & =\text { Jumlah total sampel } \\
\mathrm{X} \% & =\text { Persentase hasil variable yang dihitung }
\end{array}
$$

\section{HASIL DAN PEMBAHASAN}

\section{Hasil}

Pada hasil penelitian, didapatkan pasien TB paru dengan terapi Obat Anti Tuberkulosis (OAT) yang melakukan pemeriksaan Hemoglobin dan Leukosit di RSIJ Cempaka Putih periode Januari-Juni 2019 sebanyak 109 pasien.

Tabel 1

Distribusi frekuensi jenis kelamin penderita TB paru yang melakukan pemeriksaan Hemoglobin dan Leukosit Di RSIJ Cempaka Putih

\begin{tabular}{ccc}
\hline Jenis kelamin : & Jumlah (Orang) & Persentase \\
\hline Laki-laki & 72 & $66 \%$ \\
\hline Perempuan & 37 & $34 \%$ \\
\hline
\end{tabular}

Dari tabel 1. didapatkan jumlah penderita Tuberkulosis Paru yang melakukan pemeriksaan Hemoglobin dan Leukosit di RSIJ Cempaka Putih tahun 2019 yang berjenis kelamin laki-laki sebanyak 72 orang (66\%) dan pada perempuan sebanyak 37 orang (34\%) 
Tabel 2

Distribusi Frekuensi Penderita Tuberkulosis Paru di RSIJ Cempaka Putih tahun 2019 Berdasarkan Usia.

\begin{tabular}{ccc}
\hline Berdasarkan usia & Frekuensi & Persentase \\
\hline$<30$ tahun & 30 & $27 \%$ \\
\hline $31-40$ tahun & 17 & $16 \%$ \\
\hline $41-60$ tahun & 50 & $46 \%$ \\
\hline$>60$ tahun & 12 & $11 \%$ \\
\hline Total & $\mathbf{1 0 9}$ & $\mathbf{1 0 0 \%}$ \\
\hline
\end{tabular}

Dari tabel 2. didapatkan penderita Tuberkulosis Paru di RSIJ Cempaka Putih tahun 2019 menurut kategori usia, (<30 Tahun) sebanyak 30 orang (27\%), (31-40 Tahun) sebanyak 17 orang (16\%), (41-60 Tahun) sebanyak 50 orang (46\%), (>60 Tahun) sebanyak 12 orang (11\%).

Tabel 3

Distribusi frekuensi hasil pemeriksaan kadar Hemoglobin dan Leukosit pada penderita Tuberkulosis Paru di RSIJ Cempaka Putih.

\begin{tabular}{ccc}
\hline Kadar & Hemoglobin & Leukosit \\
\hline Normal & $34(31 \%)$ & $70(64 \%)$ \\
\hline Abnormal & $75(69 \%)$ & $39(36 \%)$ \\
\hline Jumlah & $\mathbf{1 0 9}(\mathbf{1 0 0 \% )}$ & $\mathbf{1 0 9}(\mathbf{1 0 0 \% )}$ \\
\hline
\end{tabular}

Berdasarkan Tabel 3. menunjukan persentase Hemoglobin dan Leukosit pada penderita Tuberkulosis Paru, terdapat 34 orang (31\%) dengan hasil Hemoglobin sesuai dengan nilai normal dan sebanyak 75 orang (69\%) dengan hasil kurang dari nilai normal. Kemudian hasil pemeriksaan Leukosit terdapat 70 orang (64\%) sesuai dengan nilai normal dan sebanyak 39 orang (36\%) melebihi nilai normal.

Tabel 4

Distribusi Frekuensi Penderita Tuberkulosis Paru Berdasarkan Lamanya Mengkonsumsi OAT di RSIJ Cempaka putih

\begin{tabular}{ccccc}
\hline $\begin{array}{c}\text { Lamanya } \\
\text { Mengkonsumsi } \\
\text { OAT }\end{array}$ & Hemoglobin & Hemoglobin & Leukosit & Leukosit \\
\hline & Normal $(\boldsymbol{\%})$ & $\begin{array}{c}\text { Abnormal } \\
(\boldsymbol{\%})\end{array}$ & $\begin{array}{c}\text { Normal } \\
(\boldsymbol{\%})\end{array}$ & $\begin{array}{c}\text { Abnormal } \\
(\boldsymbol{\%})\end{array}$ \\
\hline 1 bulan & $15(14 \%)$ & $7(6 \%)$ & $19(17 \%)$ & $3(3 \%)$ \\
\hline $\mathbf{2}$ bulan & $3(3 \%)$ & $25(23 \%)$ & $11(10 \%)$ & $17(15 \%)$ \\
\hline 3 bulan & $10(9 \%)$ & $23(21 \%)$ & $22(20 \%)$ & $11(10 \%)$ \\
\hline 4 bulan & $6(5 \%)$ & $20(18 \%)$ & $18(16 \%)$ & $8(7 \%)$ \\
\hline Jumlah & $34(31 \%)$ & $75(69 \%)$ & $70(64 \%)$ & $39(36 \%)$ \\
\hline
\end{tabular}

Berdasarkan Tabel 4. Menunjukan bahwa dari 109 orang penderita Tuberkulosis Paru paling banyak memiliki kadar Hemoglobin sesuai dengan nilai normal sebanyak 14\% dengan lamanya mengkonsumsi OAT selama 1 bulan dan 23\% kadar Hemoglobin kurang dari nilai normal dengan 
lama mengkonsumsi OAT selama 2 bulan. Kemudian hasil pemeriksaan Leukosit sesuai dengan nilai normal sebanyak 18\% dengan lamanya mengkonsumsi OAT selama 4 bulan dan 15\% jumlah Leukosit lebih dari nilai normal dengan lamanya mengkonsumsi OAT selama 2 bulan.

\section{Pembahasan}

Hasil penelitian berdasarkan jenis kelamin pada penderita Tuberkulosis Paru dapat dilihat pada Tabel 1. Berdasarkan hasil penelitian yang didapat menunjukkan penderita Tuberkulosis paru lebih banyak pada laki-laki (66\%) dibanding perempuan (34\%). Hal ini sesuai dengan pernyataan Hiswani yang dikutip oleh WHO (2014), Bahwa penderita TB paru cenderung lebih tinggi laki-laki dibandingkan perempuan. Pada jenis kelamin laki-laki penyakit ini lebih tinggi karena merokok tembakau dan minum alcohol sehingga menurunkan sistem pertahanan tubuh, sehingga lebih mudah terpapar agen penyebab Tuberkulosis Paru.

Hasil penelitian yang diambil berdasarkan kriteria umur pada penderita Tuberkulosis dapat dilihat pada Tabel 2. Menunjukan bahwa penderita Tuberkulosis pada usia muda atau produktif $46 \%$ lebih banyak. Penelitian ini sejalan dengan penelitian Hiswani (2004) bahwa penderita penyakit Tuberkulosis paling sering ditemukan pada usia muda atau produktif yang berkisar antara 17-59 tahun. Hal ini terjadi karena usia produktif mayoritas orang banyak menghabiskan waktu untuk bekerja sehingga membutuhkan tenaga yang besar dan ditambah lagi dengan istirahat yang kurang yang dapat menyebabkan daya tahan tubuh menurun dan rentan terkena penyakit TB. Selain itu lingkungan yang padat dan menjalin komunikasi dengan banyak orang yang mungkin sebagai penderita TB sehingga tidak menutup kemungkinan tidak terinfeksi atau terpapar oleh bakteri penyebab penyakit TB, karena penuluran TB sendiri bisa melalui percikan dahak (droplet nuclei) pada saat orang yang terinfeksi tersebut batuk ataupun bersin.

Hasil penelitian berdasarkan kadar hemoglobin dan Leukosit pada penderita Tuberkulosis paru dapat dilihat pada Tabel 3. Didapatkan hasil hemoglobin yang normal sebanyak 34 orang (31\%) dan yang abnormal sebanyak 75 orang (69\%) dan rata-rata leukosit yang normal sebanyak 70 orang (64\%) dan yang abnormal sebanyak 39 orang (36\%).

Hasil penelitian berdasarkan lamanya pengobatan pada penderita Tuberkulosis Paru dapat dilihat pada Tabel 4. Didapatkan hasil rata-rata kadar hemoglobin menurun pada lama pengobatan selama 2 bulan sebanyak 28 orang (26\%) Hal ini sejalan dengan pendapat Ida Fauziah (2011), lama pemberian OAT berpengaruh signifikan terhadap penurunan kadar hemoglobin mulai dari bulan kedua sampai bulan ketiga pengobatan. Menurunnya kadar hemoglobin penderita tuberkulosis dapat disebabkan karena proses infeksi tuberkulosis dan obat anti tuberkulosis pada fase awal terdiri dari Isoniazid, Pirazinamid dan Rifampisin dan Etambutol pada fase lanjutan hanya terdiri dari Isoniazid dan Rifampisin dan Etambutol. Pemberian Isoniazid dan Pirazinamid dapat menyebabkan gangguan metabolisme B6 sehingga meningkatkan ekskresi B6 melalui urine dan dapat mengakibatkan defisiensi B6. Vitamin B6 
dalam bentuk pyridoxal phosphate merupakan kofaktor dalam proses biosintesis heme. Defisiensi B6 akan mengganggu biosintesis heme dan mengakibatkan anemia sideroblastik sedangkan pemberian Rifampisin dapat menimbulkan anemia hemolitik. Dan nilai rata-rata Leukosit meningkat pada lamanya pengobatan yaitu 2 bulan sebanyak 17 orang (15\%) penelitian ini sesuai dengan Syarifah khairsani dkk (2017) bahwa adanya peningkatan jumlah Leukosit pada penderita Tuberkulosis paru menunjukan adanya pembentukkan leukosit yang banyak untuk melawan bakteri penyebab penyakin TB Paru dalam proses fagositosis secara keseluruhan (Kemenkes RI, 2011).

\section{SIMPULAN}

Dari hasil pemeriksaan Hemoglobin dan Leukosit pada pasien TB paru di Laboraturium RSIJ Cempaka Putih Tahun 2019 berdasarkan penelitian 109 pasien terapi OAT peneliti dapat mengambil kesimpulan sebagai berikut : Penderita Tuberkulosis paru berdasarkan jenis kelamin banyak dialami oleh penderita yang berjenis kelamin laki-laki sebanyak 72 orang $(66 \%)$. Penderita Tuberkulosis berdasarkan kelompok usia banyak ditemui pada kelompok usia 41-60 tahun sebanyak 50 orang 46\%. Didapatkan penderita tuberkulosis paru sebagian besar memiliki kadar Hemoglobin tidak normal sebanyak 75 orang (69\%) dan nilai rata- rata leukosit tidak normal sebanyak 39 orang (36\%). Dan didapatkan penderita Tuberkulosis paru memiliki kadar hemoglobin yang tidak normal pada pengobatan selama 2 - 3 bulan sebanyak (28\%).

\section{UCAPAN TERIMA KASIH}

Penulis mengucapkan terima kasih kepada kepala laboratorium RSIJ Cempaka Putih Dan Prodi D III Analis Kesehatan Universitas MH Thamrin berperan serta dalam penelitian ini.

\section{DAFTAR PUSTAKA}

1. Andareto, obi. Penyakit Menular: mengetahui macam-macam penyakit yang dapat menular. Jakarta: Pustaka Ilmu semestaa, 2015.

2. Crowin, Elizabeth.J. (2009) Buku Saku Patofisiologi Jakarta : Kedokteran EGC.

3. Dewi, Kemala, N. Profil Hematologi Pasien Tuberkulosis Paru BTA Positif Kasus Baru Sebelum dan Sesudah Pemberian Obat Anti Tuberkulosis Kategori 1 Fase Intensif. Jakarta,2014.

4. Depkes RI, 2011. Pedoman Nasional Penanggulangan Tuberculosis. Jakarta: Depkes RI.

5. Depkes RI, 2015. Pedoman Nasional Penanggulangan Tuberkulosis. Jakarta: Depkes RI.

6. Kemenkes RI, 2011. Pedoman Nasional Penanggulangan Tuberkulosis. Kemenkes RI: Jakarta.

7. Kemenkes RI, 2013. Pedoman Naional Pelayanan Kedokteran Tata Laksana Tuberkulosis Kemenkes RI.:Jakarta. 
8. Kemenkes RI, 2015. Profil Kesehatan Indonesia Tahun 2015. Jakarta: Kemenkes RI.

9. Kemenkes RI, 2016. Profil Kesehatan Indonesia Tahun 2016. Jakarta: Kemenkes RI.

10. Kemenkes RI. Pedoman Nasional Penanggulangan Tuberkulosis 2014. Diakses pada http://www.tbindonesia.or.id/opendir/Buku/bpn p-tb 2014.pdf, 2014.

11. Kemala, Naindra.D,. Profil Hematologi Pasien Tuberkulosis Paru Bta Positif Kasus Baru Sebelum Dan Sesudah Pemberian Obat Anti Tuberkulosis Kategori 1 Fase Intensif. Jakarta 2014.

12. Kiswari, Rukman. 2014 Hematologi \& Transfusi. Jakarta Erlangga

13. Lasut, N.M.,2014.Gambaran Kadar Hemoglobin dan Trombosit pada Pasien Tubercolusis Paru di RSUP Prof.DR.R.D kandou Periode Januari-Desember 2014. Ringkasan Penelitian. Manado: Universitas SamRatulangi.

14. Rezki, Kini,. Pemantauan Efek Samping Obat Anti Tuberkulosis (Oat) Pada Penderita $\mathrm{Tb}$ Dalam Pengobatan Tahap Intensif Di Bbkpm Kota Makassar. Makassar 2017.

15. Syarifah Khaironi,dkk. Gambaran Jumlah Leukosit Dan Jenis Leukosit Pada Pasien Tuberkulosis Paru Sebelum Pengobatan Dengan Setelah Pengobatan Satu Bulan Intensif Di Puskesmas Pekanbaru. Pekanbarun 2017.

16. Masriadi,. Epidemiologi Penyakit Menular Cetakan ke-2, Penerbit : PT Raja Grafindo Persada, Depok 2017.

17. Misnadiarly. 2006. Mengenal, Mencegah, Menanggulangi TBC Paru, Ekstra Paru, Anak, dan pada Kehamilan. Jakarta: Populer Obor.

18. Najmah., Epidemiologi Penyakit Menular, Taufik Ismail (Ed), Penerbit : Trans Info Media, Jakarta 2016

19. Widoyono. 2008.Penyakit Tropis Epidemiologi, Penularan,Pencegahan dan Pemberantasannya. Jakarta: Erlangga.

20. World Health Organization. Global tuberculosis report 2013. WHO Library Cataloguing-inpublication Data.2013. 